\title{
İngiltere'nin Ankara İle İlişki Kurma Çabaları ve Rawlinson'un Rolü
}

\author{
Yrd. Doç. Dr. Rahmi DOĞANAY* \\ ÖZET
}

İtilaf Komiseri sifatıyla Kafkasya ve Doğu Anadolu'da faaliyetlerde bulunan Albay Rawlinson bir İngiliz subayıdır. İtilaf Komiseri olmasının yanında, Ingiltere'nin Türkiye ve Kafkasya siyasetini yönlendirmek gibi bir misyonu da üstlenmiştir. 1919-1921 yıllarını kapsayan bu dönemde Rawlinson askeri ve siyasi olmak üzere iki misyon üstlenmiş, siyasi misyonu gizli tutulmaya çalışılmıştır. Ingiltere'nin TBMM Hükümeti ile uzlaşma çabalarına da müdahil olan Rawlinson, Ístanbul'un işgali üzerine gözaltına alınmıs, 1921 Ekim ayı sonunda Malta Sürgünleri ile mübadele edilerek Türkiye'den ayrılmıştır.

Anahtar Kelimeler; Rawlinson, Erzurum, Ingiltere, Ankara

\section{ABSTRACT}

\section{Alliance Commisioner Rawlinson's Political Mission}

Colonel Rawlinson is an English Officer Who made some actions in Caucasian and East Anatolia as alliance commisioner. He had a mission to direct England's policy on behalf of England towards Turkey and Caucasia besides being an Alliance Commisioner. In that era covering the years 1919-1921 Rawlinson had two missions, one was military and the other was political. He tried to hide his political mission.

Rawlinson, Who was a member of the efforts of agreement between England and TGNA(Turkish Grand National Assembly), left Turkey towards the end of December, 1921.

Keywords; Rawlinson, Erzurum, England, Ankara

' Fırat Üniversitesi, Fen-Edebiyat Fakültesi, Tarih Bölümü. 
1919-1921 tarihleri arasında (bir bölümü tutsak olarak) Erzurum ve çevresinde bulunmuş olan Rawlinson, 1918 Bakü harekatına ${ }^{1}$ katılmış bir İngiliz subayidır. ${ }^{2}$ İngiliz aristokrasisinden bir aileye mensup olan bu subay, ${ }^{3}$ bölgede gezdiği yerlerin sosyal, siyasi ve iktisadi yapısı hakkındaki gözlemlerini hatıra olarak kaleme almış, bu hatırat, daha 1923'te Londra'da, hemen sonrasında da Amerika'da basılmıştı. 1919 yılının başlarında sözde Mondros Mütarekesi'nin uygulanışını denetlemek göreviyle Doğu Anadolu ve Kafkasya’ya gönderilmişti., Bölgeye yönelik İngiliz politikalarının alt yapısını oluşturma misyonu gizli tutulmuştu.

Rawlinson, Selanik Seferi Kuvvetleri istihbarat șubesine bağlı özel servis subayı olarak görevlendirilmiş, bu görev için Sir George Milne ${ }^{4}$ referans olmuștur. 15 Şubat'ta 1919 'da Londra'dan ayrılmış, İtalya üzerinden gemiyle Selanik'e, oradan da 1 Mart 1919'da İstanbul'a ulaşmıştır. Resmi görevi Kafkasya ve Doğu Anadolu'da Mütareke hükümlerinin uygulanması denetlemek ve Müttefik Yüksek Konseyi'nin barıș şartlarına yönelik inceleme de bulunmak ${ }^{5}$ olarak belirlenmiştir. Ancak

' Bu harekatla ilgili olarak [Bkz. Taylan Sorgun, Halil Paşa İttihat ve Terakki'den Cumhuriyet'e Bitmeyen Savaş, İstanbul 1997, s. 226 vd.] Rawlinson'a göre, 1918'de Bakü ve Kafkasya'ya giren İngiliz birlikleri Bolşevik Ermeni yönetimi tarafından yardıma çağrılmıştı. Dolayısıyla İngiltere bir yandan Bolşevik Rusya'yı boğmaya çalışırken, diğer yandan Bolşevik Ermenilere yardım etmektedir. 1918 yılında bölgedeki seyahati ve faaliyetleri hakkında bkz. A. Rawlinson, The Adventures in The Near East, London 1923, s.7-78 ve ayrıca bkz. Peter Hopkirk, İstanbul'un Doğusunda Bitmeyen Oyun, İstanbul 1995 , s.220

${ }^{2}$ Bkz. A. Rawlinson, Adventures in The Near East, London 1923, s.63

${ }^{3}$ Rawlinson'un ağabeyi Sir Henry Rawlinson İngiliz Hindistan Genel Valiliği görevine kadar yükselmiș ender bürokratlardan birisi olup, daha sonra da Arkanjel Müttefik Kuvvetleri Komutanlığına tayin edilmiştir.[Bkz. A. Rawlinson, a.g.e., s.123] Bazı Türk kaynakları İngiliz idaresi nezdinde Rawlinson kardeşlerin önemini fark etmiş olduklarından A . Rawlinson'u Lord Curzon'un kardeşi [Bkz. K. Karabekir, İstiklal Harbimiz, İstanbul 1988, s.983] veya yeğeni olarak [Bkz. Gotthard Jaeschke, Kurtuluş Savaşı ile İlgili İngiliz Belgeleri, Ankara 1986, s.148] gösterirler. Gerçekte A. Rawlinson Lord Curzon'un yeğeniyle evlenmiştir. Bkz. Fahrettin Kırzıoğlu, Türk İnkılap Tarihi Dersleri, Erzurum 1977, s.61. Alfred Rawlinson'un ailesiyle ilgili bir başka kaynakta da; "Sir Henry Rawlinson'un Alfred'in babası" olduğu şeklinde farklı bir bilgi yer almaktadır. [Bkz. P. Hopkirk, a.g.e., s.220] Alfred Rawlinson ise kendi hatıratında Henry ile kardeş olduklarını açıkça ifade etmektedir. Bkz. A. Rawlinson, a.g.e., s.123.

${ }^{4}$ Rawlinson, Selanik Seferi Kuvvetleri Başkomutanı Sir George Milne ile, Arkanjel'deki İngiliz kuvvetlerinin tahliyesi sorumluluğunu yüklenen kardeşi (Sir Henry Rawlinson ile kahvaltı ederken tanışmıştır. Bu kuvvetler Hazar Denizi'ni aşıp Bakü’ye geçerek, Kafkaslardaki diğer kuvvetlerle birlikte harekat yapacak olan Kuzey İran ordularına katılmak için İstanbul'a nakledilmekteydi. Sir George Milne, adı geçen yerleri bildiğini işitince Rawlinson'a maiyetinde özel bir görev verilmesini sağlamıştır. Bkz. A. Rawlinson, a.g.e., s.123.

${ }^{5}$ Seçil Akgün, General Harbord'un Anadolu Gezisi ve Ermeni Meselesine Dair Raporu, İstanbul 1981, s.53, Erzurum'a gitmekte olan rawlinson, Trabzon'da kendisine Sultan'ın itimatnamesinin ve Harbiye Nezareti'nin izin belgesinin verildiğini ve burada 
daha sonraki faaliyetleri çerçevesinde istihbari bir görev yüklendiği de anlaşılmaktadır. Nitekim Rawlinson İstanbul'da fazla kalmayarak, Ingiltere'nin Kafkasya'daki istihbarat sorumlusu General Beach'e katılmak üzere 5 Mart'ta ayrılmış ve Karadeniz yoluyla 10 Mart'ta Batum'a ulaşmıştı. Oradan Tiflis'e geçmiş, Beach ile görüşmüş, ${ }^{6}$ Mart ayı sonuna kadar Tiflis, Tebriz, Bakü, Kars bölgelerinde incelemelerde bulunduktan ${ }^{7}$ sonra 3 Nisan'da Batum üzerinden deniz yoluyla Trabzon'a, Gümüşhane yoluyla 22 Nisan 1919'da Erzurum'a gelmiştir. ${ }^{8}$

Rawlinson 23 Nisan 1919'da vali ve karargah geçici komutanı Albay Rüştü ile görüşmüş, itimatnamesini göstererek, silah ve mühimmat depolarını, yoklama cetvelleri ve bordroları incelemiştir. 27 Nisan'da Kars'ta İngiliz Kuvvetleri Karargah Komutanı Beach bir rapor sunarak tekrar Erzurum'a dönmüş, teftişini tamamlayıp, Osmanlı kuvvetlerinden toplanan silahların Ermenistan'a sevki görevini almıștır. ${ }^{9} \mathrm{Bu}$ arada Mayıs ayı başlarında IX Ordu'nun yeniden düzenlenmesiyle oluşturulan XV. Kolordu'nun kumandanlığına; Erzurum'a tayin edilen Kazım Karabekir ile

Osmanlı kuvvetlerinin tasfiyesi konusunda incelemeler yaptığını ifade etmektedir. Bkz. A. Rawlinson, a.g.e., s.167.

${ }^{6}$ Rawlinson Beach ile İran'dan tanışmaktadır. Tiflis'te 14 kişilik ekibini oluşturarak onları eğitmiştir. Ekipteki görevliler yaver, tercüman, şoför, aşçı, seyis, emir eri kadrolarında, kamufle edilmişlerdir. Bkz. A.Rawlinson, a.g.e., s.140-143.

${ }^{7}$ Kars ile ilgili izlenimlerinde, Kars'ta nüfusun büyük çoğunluğunu Türklerin oluşturduğunu tespit eden Rawlinson, Kars'ta kurulan Türk Hükümeti'nin Wilson Prensiplerine dayandığını, Türklerce desteklendiğini, İngilizlerin bu kargaşayı önlemeye geldiğini ve Yüksek Konsey'in Kars'ı Ermenilere verme kararının da Müttefiklerin ilk büyük hatalarından olduğunu ve Müslümanların tepkilerinde haklı olduğunu kaydetmektedir. [A.Rawlinson, a.g.e., s.153], Rawlinson'un görüşleri, bin yıldır Türklerin egemenliğinde bulunan bölgede başka bir unsur müdahalesinin getireceği büyük tepkiyi belirtiyordu. Bkz.Cevat Dursunoğlu, Milli Mücadele'de Erzurum, Ankara, 1946, s.71.

${ }^{8}$ Rawlinson Erzurum'a gelirken Yakup Şevki Paşa da ordusu lağvedilerek İstanbul'a çağrılmıştır. Ancak, Ordunun çekilmekte olduğu bu bölgelerde milis kuvvetleri oluşturulmuş ve yabancı müdahalelerine karşı mücadeleye devam etmektedir. [Bkz. Birinci Dünya Harbinde Türk Harbi, Kafkas Cephesi, Ankara 1993, s.780,] Bu sebeple Rawlinson Trabzon üzerinden Erzurum'a gitmeyi tercih ediyor. Yakup Şevki Paşa İstanbul'a dönerken, Erzurum'a gelmekte olan Rawlinson ile Gümüşhane'de karşılaşırlar. [Bkz. A.Rawlinson., a.g.e., s.170] Rawlinson'un ve ekibinin Erzurum'a gitmek için Trabzon'a geldiği ve bölgedeki görevleri hakkında Trabzon Mevki Kumandanlığı Erzurum'u önceden haberdar etmiştir. Bkz. Erzurum'dan harbiye Nezareti'ne konuyla ilgili olarak yazılan 22.4.1335(22.4.1919) tarihli rapor. ATASE Arşivi, Kls.76, K.88, Göml.190.

${ }^{9}$ Rawlinson, Erzurum civarında toplanan silahların tren yoluyla Trabzon'a sevk edilmek amacıyla Ermeni sınırına taşınmasını istemiştir. Ancak Türk ahalinin endişesi, silahların Ermenilere verileceğidir. [Bkz. A.Rawlinson, a.g.e, s.175 vd.] İstanbul'dan Müttefik Orduları Başkumandanlığı emriyle Mütareke'nin uygulanmasına yönelik talimatlarla 15. Kolordu mıntıkasına gelen 15. Fırka Kumandanı Rüşdü, 15. Kolordu Komutanlığı'na 5.5.1335(5.5.1919) tarihli raporla Mütarekenin uygulanması konusundaki emirleri ve Rawlinson'un da bölgeye gelmiş olduğunu bildirir. Rapor için bkz. ATASE Arşivi, Kls. 78, K.90, Göml. 67. 
de görüşen İngiliz İtilaf Komiseri Rawlinson, 3 Haziran 1919'a kadar Kars ve Erzurum yöresinde incelemelerde bulunmuş ve Mütareke hükümlerinin uygulanmasını sağlamaya çalışmıştır.

Rawlinson bölgedeki incelemelerinin sonucunda, Türklerin geleceğinin bu coğrafyada belirleneceğini fark etmiştir. O'na göre; Türkler burada alacakları sonuçlara göre geleceklerini planlayacaklardır. İngiliz subayının fark ettiği başka bir husus da; teftiş konusunda her türlü kolaylığın gösterilmesine rağmen, silahsızlanma konusunda işlerin savsaklandığıdır. Bunu amirlerine bildirir.

Bu sıralarda Kazım Karabekir de Erzurum'a gelmiştir. Rawlinson'un sıkıntısı bölgedeki depoların denetlenmesinden değil, geçitlerin kapalı olması ve kar yüzünden doğu sınırındaki işlerin yürümemesi, nakliyatın yapılamamasıdır. Kazım Karabekir de toplayacağı silahları sevk etmesinin imkansızlığını vurgulayarak, Türk ahalinin buna müsaade etmeyeceği konusunda Rawlinson'u uyarmıştır. ${ }^{10}$ Aslında Rawlinson da, Türk ordusunun

${ }^{10}$ Karabekir ile görüşen Rawlinson kendisine iltifatlarda bulunmuştur. Karabekir'in görüşme ile ilgili ifadeleri ise şöyledir: "Ingiliz Albay ziyaretime geldi. Vazifesini sordum. Doğu bölgesinde Mütareke hükümlerinin iyi uygulanması dedi. O halde kolordu ve fırkalara emir verir gibi yazmamasını istedim. Arzunuzu bana söylersiniz, ben gereğini yaparım. İcraya ait işler Harbiye Nezareti'nin emriyle olur dedim. Öte beriye fazla müdahalen asabi halk üzerinde kötü etki yapar. Ne sen, ne de ben hayatımızı tehlikeye atmayalım dedim. Rawlinson makul karşıladı." Karabekir Rawlinson her konuda kendisine gelmesin diye Fransızca bilen bir subayı aracı tayin etmiştir. Subayın İngilizce de bildiğini Rawlinson bilmemektedir. Karabekir, Rawlinson'un dairesindeki görüşme ve yazışmalardan bu yolla haberdar olmaktadır. Rawlinson bu konuda umutsuzdur. Karabekir, kendisinin silah ve mühimmatları teslim etmemek için bahaneler ararken, Rawlinson'un kendisini Bolşevikler konusunda bir harekata sürüklemeye çalıştığı izlenimini de aktarır. Fazla silahların şimendiferle sevk edilmesi teklifine yolların bozukluğunu ileri sürerek karşı çıkar. [Bkz, K.Karabekir, İstiklal Harbimiz, İstanbul 1988, s.21 vd.] Rawlinson Karabekir'i şöyle tasvir eder: "Kazım Paşa hoş sohbet, zeki, milletlerarası meselelere müstesna bir vukuf sahibiydi. Memleketinin geleceği ve Milli Hareket ile ilgili görüşlerinden ve neticelerinden şüphem yoktu. Kazım Paşa birinci sınıf Türk subaylarından bir örnekti. Savaş tecrübesi çoktu. O'nun komuta ettiği bir ordunun iyi komuta altında olduğuna her zaman güvenilebilir. Uzun zaman elinde esir bulunmam ve her türlü zorluklara katlanmama rağmen Paşa'nın şahsına her zaman saygı duydum. Türklerin batıda kazandıkları zaferlerde Kazım Paşa'nın doğuda karışık bir durumu bilgili bir şekilde ele almasının büyük payı vardır." Bkz. A.Rawlinson, a.g.e., s.181, K. Karabekir, İstiklal Harbimizin Esasları, İstanbul 1995, s.308. 
silahsızlandırılma uygulamasını "çok keyfi bir muamele" olarak gördüğünü ve bu işi sadece emirleri uygulamaya çalıştı̆̆ını Karabekir'e ifade ederek vicdani rahatsızlığını açı̆̆a vurmuştur. ${ }^{\natural}$ Ancak aynı Rawlinson, bu süre içindeki deneyimlerinden hareketle; işlerin istediği hızla yürümediğini ve bunun sağlanması için bir miktar İngiliz askerinin yardımına gönderilmesi isteğini bir raporla üstlerinden istemiștir. 21 Haziran'da General Beach'i hudutta karşılamış ve birlikte Erzurum'a gelmişlerdir. ${ }^{12}$ General Beach, 3 Haziran'da Tiflis'e dönerken, Rawlinson'a yardımı vaadinde bulunmuş, gerçekten de 2 istihbarat subayı, 2 tercüman, 8 at, 2 katır, 1 doktor, tıbbi malzeme, 2 asteğmen ve 20 erden mürekkep küçük bir kuvveti ${ }^{13}$ göndermiş̧ir.

7 Temmuz'da Trabzon üzerinden Batum'a giden Rawlinson, Türk yetkililerin Mütareke şartları konusunda zorluk çıkardıkları şikayetinde bulunmuş ve Beach'den bu konuda talimat almıştır. Tekrar Erzurum'a döndügüunde ve Kazım Karabekir'in Ermeni saldırılarına müdahale etmesini istemesi üzerine, olayı yerinde incelemek üzere bazı girişimlerde bulunmuştur. Bu sırada Mustafa Kemal de Erzurum'a gelmiștir. ${ }^{14}$ Erzurum Kongresini dikkatle takip eden Rawlinson, bir ara bunu önleyebilmek için Mustafa Kemal'i tehditkar bir ifadeyle uyarmaya kalkışmış, dikkate alınmamıştır. ${ }^{15}$

Rawlinson, Kazım Karabekir'in kendisine tahsis ettiği bir dekovil treni ile Kars bölgesine giderek Ermeni zulmünü incelemiş, Türklerin şikayetlerinde haklı olduğunu görmüş, Ermeni zulmüne dair deliller bulduğunu da ifade etmiştir. Gümrü'deki Ermeni karargahından sağlayacağ yardımla hem demiryolunun tamirini hem de silahların taşınmasını

${ }^{11}$ A. Rawlinson, a.g.e., s.184.

12 İki İngiliz subayı Karabekir ile görüşürler. 2 Haziran'da yapılan bu görüşmede Rawlinson, Müttefiklerin bölgeyi bilmeden yanlış bir karar verebilecekleri endişesini ve Ermenilerin buralara hakim olamayacağı kanaatini kendisine aktardığını söyler. Beach de silahların şimendiferle Sarıkamış'a, oradan da Batum'a taşınması teklifini yapar ve Karabekir bunu kabul etmiş görünür. Bu arada Beach, Üçüncü Fırka Kumandanı Halit Beyi de sorar. Halit Beyi tutuklamak istemektedirler. Karabekir, Halit Bey'in ortalıktan kaybolduğu cevabıyla bu soruyu geçiştirir. Bkz. K. Karabekir, İstiklal Harbimiz, s.31,39, ayrıca bkz. A.Rawlinson, a.g.e., s.184.

${ }^{13}$ Bu sırada Rawlinson'un beklediği takviye güç ve malzeme de Trabzon'a ulaşmış, 8 Temmuz'da bizzat Rawlinson'a teslim edilmiştir. Bkz. A.Rawlinson, a.g.e., s. 184.

${ }_{14}$ Mustafa Kemal'in Müttefiklerin isteği ile İstanbul'a çağrıldığından ve askerlik rütbesinden mahrum edildiğinden bahseder. Bkz. A.Rawlinson, a.g.e., s.190.

${ }^{15}$ Gerçekten de Rawlinson 9 temmuz'da Mustafa Kemal ile görüşmüş ve Kongre'nin toplanmamasını istemiş ise de, bu dileği reddedilmiştir. Rawlinson'a göre Mustafa Kemal, ezeli düşmanı olmasına rağmen, Enver'i desteklemeyi taahhüt etmiştir. Bu arada Mustafa Kemal'i sık sık gördügüunü ve Erzurum Kongresi çalışmalarının da takip ettiğini belirten Rawlinson'u [Bkz. A.Rawlinson, a.g.e., s.189] Mazhar Müfit de doğrulamaktadır. Bkz. M Müfit Kansu, Erzurum'dan Ölümüne Kadar Atatürk'le Beraber I, Ankara,1966, s.47. 
sağlamayı düşünen Rawlinson, Erzurum'da toplanan silahların Ermeni sınırına getirilerek Ermeni tarafındaki trenlere aktarılmasını Karabekir'den istemiştir. Bu yolla silahlar sahile taşınabilecektir. Aktarma için Zivin istasyonu seçilmiştir. Rawlinson Zivin'e geldiğinde; demiryolu subayı ve iki erin beklediği silahla dolu trenin eşkıya kılıklı kişiler tarafından soyulduğunu, subay ve erlerin bir vagona kapatılarak, silahların katırlar tarafından çekilen bir vagon kervanıyla dağa taşındığını öğrenmiştir. Kazım Karabekir ile yaptığı yazışmadan Karabekir'in olaydan haberdar olduğunu, olayın halk tarafından gerçekleştirildiği kanaatinde bulunduğunu öğrenmiş̧tir. Rawlinson bunun bir tertip olduğunu fark etmiş ancak bu tertibi anlamamış görünmekten başka çaresi olmadığın $1^{16}$ düşünmüştür.

Rawlinson bu tahmininde haklıdır. Olay gerçekte planlı bir tuzaktır. Sivil giydirilmiş askerler tarafından düzenlenmiş, halk veya eşkiyalar tarafından gerçekleştirilmiş görüntüsü verilmiştir. Zivin'deki (Taşkesen) Türk subayı Binbaşı Emin Bey Karabekir'e durumu bu çerçevede rapor etmiştir. Karabekir uygulamadan gayet memnun olarak olayı Rawlinson dahil ilgili makamlara rapor edip, Mustafa Kemal'i de bilgilendirmiştir. Tren gittiği gibi Erzurum'a geri gelmiştir. 27 Temmuz'daki Rawlinson-Karabekir görüşmesinde gündeme gelen konu, Rawlinson-Mustafa Kemal görüşmesinde de tartışılmıştır. ${ }^{17}$

26 Temmuz'da Erzurum'a ulaşan Rawlinson, adeta ayağının tozuyla, bir gün sonra Karabekir ile görüşmüş, Karabekir'den; “İngilizlerin isteklerine cevap verecek durumda olmadı̆̆ı, Kongre'nin devam ettiği, memleketin karışık olmasından dolayı, gerekli emirleri verecek konumda olsa bile silahların sınırdan geçirilmesine halkın izin vermeyeceği kesin cevabını almıştır. ${ }^{18}$ Rawlinson da Karabekir'e teşekkür etmiş, durumu Türk telleriyle hükümetine bildirmek için müsaade istemiş ve acilen İstanbul'daki İşgal Kuvvetleri Komutanını bilgilendirmiştir. ${ }^{19}$ Aynı telgrafı sınırdaki irtibat

${ }^{16}$ A.Rawlinson, a.g.e., s. 230 ve ayrıca K. Karabekir, İstiklal Harbimiz, s. 82 vd.

17 K.Karabekir, İstiklal Harbimiz, s.82 vd., ayrıca bkz. Selahattin Tansel, Mondoros'tan Mudanya'ya Kadar II, s.80. Mazhar Müfit Rawlinson'un Kazım Karabekir'i Mustafa Kemal'e şikayete geldiğinden ve Paşa'nın İngilizi asabiyetle terslediğinden bahseder. Bkz. M. .M. Kansu, a.g.e., s.49, BOA, D.53-3, B.No: 15.

${ }^{18} \mathrm{Bu}$ arada Karabekir, galeyana gelen halka, “"'bizzat Rawlinson'a gidip tepkinizi gösterin” diyerek İtilaf Komiserini etkilemek ister. Ancak Rawlinson'a giden gurubun O'na çıkışacak yerde, tehditler karşısında geri çekildiklerini ve çay, kahve içip sohbet ettikten sonra, "silah işini Karabekir ile halledin" deyip geri döndüklerinden bahseder. Rawlinson heyete, aslında işi bozanın Karabekir olduğunu söylemiş, "Karabekir bertaraf edilirse Erzurum'u Ermenilere verdirmem. Öldüremezseniz taşlayın, istemeyiz diye nümayiş yapın, İstanbul'a yazın, velhasıl Doğu'dan attırın. Erzurum'u ancak böyle kurtarabilirsiniz," şeklinde tavsiyelerde de bulunmuştur. [Bkz.K.Karabekir, İstiklal Harbimiz, s.84 vd.] Buna ek olarak Rawlinson, Mustafa Kemal Paşa'yı iskat fikrini de söylemişti. Bkz. Kazım Karabekir, Enver Paşa ve İttihat ve Terakki Erkanı, İstanbul,1990, s.39.

${ }^{19}$ A.Rawlinson, a.g.e., s.226, Rawlinson'un teli üzerine, Harbiye Nezareti'ne durumu bildirip, zecri tedbirler alınması konusunda istekte bulunur. Bkz. Harp Tarihi Vesikalar 
subayı aracılı̆̆ıyla Tiflis'teki genel karargaha da çekmiştir. 28 Temmuz'da Mustafa Kemal ile yararlı bir görüşme yaptığını söyleyen İngiliz subayı görüşme ile ilgili ayrıntı vermemiştir. Ancak Mustafa Kemal'in Konferans'ta varılacak son ve resmi kararları kendisine bildireceğine söz verdiğine ${ }^{20}$ işaret etmiştir.

5 Ağustos'ta Rawlinson'a ve ekibine bütün adamlarını Türk toprakları dışına çıkarması ve kendisinin Kars'ta kalması bildirilmiştir. Bunun üzerine mahiyetine hazırlanmalarını söyleyen İngiliz İtilaf Komiseri, Karabekir'e de adamları için bir tren ayarlaması konusunda ricada bulunmuştur. 6 Ağustos'ta Karabekir ile vedalaşma esnasında Rawlinson, artık Erzurum'da İngiliz kalmayacağı, Sarıkamıș veya Kars'ta kalıp Karadeniz'den İran'a kadar sınırı gözleyecekleri konusunda söz vermiștir. Karabekir, Rawlinson'a Kolordu veznesinden muhtelif defalar 1200 lira para verildiğini de kaydeder. ${ }^{21}$ Rawlinson, Mustafa Kemal ile de üç buçuk saat süren bir görüșme yaptıklarını ve Mustafa Kemal'in kendisine o gün kabul edilen "Milli Misak" hakkında bilgi verdiğini ${ }^{22}$ ve ertesi gün son șeklini kendisine telleyeceğine söz verdiğini de kaydetmiştir. Mustafa Kemal ile Rauf Bey'in evinde görüşmüşler ve Rauf Bey de bir ara görüşmelere katılmıştır. Kuvay-1 Milliyecilerin emelleri ve gelecekle ilgili konular görüşülmüștür. Rawlinson'a göre, bu ilk defa ileri sürülen Milli Misak, Milliyetçilerin başlıca ülküsü, bütün politikalarının ve çabalarının yegane amacı olmuştur. ${ }^{23}$

Dergisi, Sayı: 3, Belge, 49 ve Bilal Şimşir, İngiliz Belgelerinde Atatürk I, Ankara 1973, s. 71-73.

${ }^{20}$ Rawlinson Mustafa Kemal’i tasvirinde: "Büyük bir Türk olan Mustafa Kemal, kuvvetli şahsiyetinin olağanüstü vasfı dolayısıyla kendisi ile temas edenler üzerinde mutlaka tesir bırakır. Tip itibariyle Asyalı'dan çok Avrupalı olan, sarı saçlı ve mavi gözlü Kemal, Türk'ten ziyade Norveçli'ye benziyor. Çok okumuş, çok yerler dolaşmıştır... Kuvvetli bir karaktere ve dünya milletler camiası içinde ırkının hakkı olan mevkiye dair gayet kesin ve pratik görüşlere sahiptir. Şahsi şöhret ve beklenti içinde değildir. Derin bir vazife duygusu beslediği için memleketinin menfaatlerini bütün diğer menfaatlerin üstünde tutmakta ve kendi kanaatince memleketi için faydalı neticeler uğrunda hiç durmadan çalışmaktadır. Hareket ve kontrol merkezini bizzat kendisinin teşkil ettiği Türk Milli Partisi'ni kurmağa muvaffak olmasının sırrı budur. Kendisi Alman usullerine göre askeri talim almıştır. Fakat gerek Rusya ve gerek Almanya'ya sempati beslediği çok şüphelidir. Bu memleketleri ancak Türkiye menfaatlerine hizmet bakımından gerekli gördüğünde desteklemektedir... Memleketinin meşru hedefleri olduğuna inandığı noktaları sebatla savunacağından ve samimiyetinden şüphelenmek imkansızdır." Demektedir. Bkz. A.Rawlinson, a.g.e, s.188.

${ }^{21}$ K.Karabekir, İstiklal Harbimiz, s.98.

${ }^{22}$ Rawlinson'un burada "Milli Misak" tan kasdı, Erzurum Kongresi kararlarıdır. Rawlinson bu kararın Türk Milli Mücadelesi için taşıdığı anlamın farkında olduğunu başkaca ifadelerinde de dile getiriyor. Ancak bu sırada Rawlinson'un "Misak-1 Milli” tabirini kullanması ilginçtir. Belki de hatıratını yazarken bu tabiri tercih etmiş olabilir.

${ }^{23}$ Bkz. A.Rawlinson, a.g.e., s.231,232, Sonyel, Mustafa Kemal-Rawlinson görüşmesinin iki saat sürdüğünü ve Mustafa Kemal'in Bolşevik eğilimini ve Enver Paşa ile işbirliğini reddettiğini, ancak Rawlinson'un buna inanmadığını yazar. Bkz. S.R. Sonyel, Türk Kurtuluş Savaşı ve Dış Politika I, Ankara,1987, s.106 ve ayrıca, Salahi R. Sonyel, "1919 
Rawlinson ve ekibi 7 Ağustos Akşamı Sarıkamış'a ulaştığında, bir telgrafla İstanbul'a çağrılmış, 14 Ağustos'ta İstanbul'a ulaşan İngiliz subayı, Beyoğlu'ndaki genel karargaha gidip Doğu illerindeki durumu etraflıca anlatarak, Milli Misak'ın bir kopyesini İngiliz İşgal Kuvvetleri Komutanı'na vermiştir. Daha sonra memleketin başka taraflarında toplanacak kongrelerde de bu Misak'nn savunulacağı ve muhakkak surette kabul edileceği kanaatini arz etmiştir. ${ }^{24}$ Yalnız 28 Ağustos'ta Londra'da Harbiye Bakanı ve diğer yetkililerle görüşerek değerlendirmelerini arz eden Rawlinson'a göre; Doğu bölgesinde Türklerin ordularını terhis ve silahsızlanmadan vazgeçerek Mütareke hükümlerini reddetmeleri hiç de sürpriz sayılmamalıdır. Bu yüzden İngiliz ordularının Kafkaslardan çekilmesini geciktirmeye çalışır ve O'nun uyarısı üzerine Batum'un boşaltılması bir müddet ertelenir. ${ }^{25}$

Rawlinson'a göre, raporları ilgiyle karşılanmış ancak, görüşleri ciddiye alınmamıştır. ${ }^{26}$ Ancak İngiliz yetkililerin bu raporları tartıştıkları ve Rawlinson'un görüşlerini $\mathrm{Az}$ da olsa dikkate aldıkları konusunda ipucu sayılacak gelişmeler de yaşanmıştır. Zira dişişleri yetkilisi olan A.R. Tilley 16 Ekim'de; “Albay Rawlinson'un işi kolay olmayacak, Mustafa Kemal'in Araplarla bir entrika çevirmemesini, Ermenileri katletmemesini, Anadolu'da olay çıkarmamasını istiyoruz... Rawlinson görüşmelerinde dostane davranırsa İtalya, Yunanistan ve belki de Fransa endişeye düşebilir. Şimdilik Mustafa Kemal'den uzak durması düşüncesindeyim." demektedir. ${ }^{27}$ Başka bir yetkili de bu görüşü kabul etmekle beraber, "kabul, fakat daha sonra Asya Türkiyesi'nde yegane canlı kuvvet olarak kendisiyle (Mustafa Kemal) anlaşmaya varmamız icab edecek..." ${ }^{28}$ görüşünü savunuyor ve Mustafa Kemal'le yakın durmayı öneriyordu. Rawlinson'un General Milne'in gizli ajanı olarak Erzurum'a gideceği de bu görüşmelerde beyan ediliyor. Buradan anlaşılan, İngilizlerin Milli Mücadele liderleriyle resmi ve açık bir ilişkiden kaçınmalarına rağmen, bu mücadeleyi yok sayarak bir sonuç alınamayacağını da fark etmişlerdir.

Yılı İngiliz Belgelerinin Işığında Mustafa Kemal ve Milli Mukavemet”, Türk Kültürü, Y1l:1969, Sayi: 85, s.46.

${ }^{24}$ A.Rawlinson, a.g.e., s.234, Sivas Kongresi'nin toplanmasıyla ilgili olarak Heyet-i Temsiliye tarafından Sivas Valisi Reşit Paşa'ya 2 Ağustos 1919'da çekilen telgrafta, milletin haklı davasının İngilizler ve Amerikalılar tarafından da tabii karşılandığı ve hatta Rawlinson'un hükümetine tafsilat ve malumat vermek için gittiği Londra'dan yazdığı mektupta tekrar dönmesinin muhtemel olduğu ve daha güzel şartlarda görüşeceklerini bildirdiği görülmektedir. Bkz. M. M. Kansu, a.g.e., s.164.

${ }^{25}$ A.Rawlinson, a.g.e., s.249.

${ }^{26}$ Rawlinson, Türk Milli Mücadelesi'nin emelleri hakkındaki görüşlerinin güvenilir bilgi olarak değerlendirilmediğini, bunlar doğru olsa bile gerçekleşmesi için Türklerin yeterli kaynak ve kuvvete sahip olmadıkları inancının Londra'da hakim olduğunu kaydeder. Bkz. A.Rawlinson, a.g.e., s.251.

${ }^{27}$ B. Şimşir, İngiliz Belgelerinde Atatürk I, s. 121.

${ }^{28}$ Bkz. S.R. Sonyel, a.g.m., s.319, ve Kurtuluş Savaşı Günlerinde İngiliz İstihbarat Servisi'nin Türkiye'deki Eylemleri, Ankara 1995, s. 30 vd. 
Londra'da hükümet ve askeri yetkililerle görüşmelerde bulunan Rawlinson, Lord Curzon'la ikinci defa görüşerek, ${ }^{29} 20$ Ekim'de Londra'dan hareketle, 6 Aralık'ta Trabzon'a ve yirmi gün sonra da Erzurum'a ulaşmıştır. Ankara-Londra ilişkilerinde barışa yönelik fazla katkısı olmasa da, Milli Mücadele'nin gelişiminde bazı gelişmeleri etkileyen, İngiltere'yi yaklaşımlarını değiştirmeye zorlayan Rawlinson'un siyasi misyonu da bu seyahat ve görüşmelerden sonra ağırlık kazanmaya başlamıştır.

Albay Rawlinson Londra'dan ayrılmadan önce Lord Curzon'la yaptı̆̆ son görüşmede Curzon'dan; "mümkünse Mustafa Kemal'i tekrar ziyaret etmesi ve imkansız olarak görülen Misak hükümleri dişında partisinin barış için ne gibi şartları kabule hazır olduğunu açık olarak tespit etmesi" talimatını almıştı. ${ }^{30}$ Ancak ilişkiler resmi yetki ve sıfatla değil, alelade askeri görevli bir subayın şahsi girișimi olarak gecçekleşmeliydi. Aksi halde öteki İtilaf Devletleri kuşkulanabilir, İngiltere'nin imajı sarsılırdı. Rawlinson Bayburt'ta bu niyetini Albay Rüştü'ye açmış, Lord Curzon ile görüşmesini aktarmış, barış imzalanırsa Osmanlı'ya söz verdiği mali yardımı Türkiye'ye yapacaklarını vaad etmişti. Daha başka bazı açıklamaları doğrudan Mustafa Kemal'e yapacağını ve Mustafa Kemal'le görüșme isteğini de bildirmiști. ${ }^{31}$ Albay Rüştü de bunları Karabekir Paşa'ya tellemişti. ${ }^{32}$

${ }^{9}$ A.Rawlinson, a.g.e., s.261.

${ }^{30}$ İngiliz İtilaf Komiseri görevini sürdürmek için yeniden Doğu Anadolu'ya gönderilen Rawlinson'a resmi bir görüntü olmaksızın Mustafa Kemal ve Kuvvacılarla bir anlaşma zemini ve barış şartlan konusunda yüklenen misyonu Rawlinson kendisi de kabul etmektedir. [Bkz.A. Rawlinson, a.g.e., s.252] İngiltere bu yaklaşımıyla Anadolu'daki mücadeleyi muhatap almış, dahası O'nun gücünü kabul etmiş olacaktı. Böyle bir görüntü ne İngiliz imajı, ne de ihtirasları açısından uygun değildi. Ancak İstanbul Hükümeti ile meseleyi çözemeyeceğini anlayan İngilizler, eğer olursa gayri resmi görüşmelerin sonucuna göre çıkarlan için alternatif politikalara yönelebileceklerdi. G. Jaeschke, a.g.e., s.148.

${ }^{31}$ S. R. Sonyel, Türk Kurtuluş Savaşı ve Dış Politika I, s.164 Rawlinson'un daha Erzurum'a ilk geldiğinde, Erzurum Kongresi sırasında, Türk milliyetçileri ile asgari anlaşma şartlarını araştırmak görevini üstlenmiş olduğunu iddia edenler de vardı. [Bkz. S. Tansel, Mondros'tan Mudanya'ya II, İstanbul 1991, s.46] Rawlinson'un Kongre sonrasında ve Kongre bildirisinin nüshası ile Londra'ya dönmesi ve yetkililerle görüşmesi bu iddianın doğru olabileceği ihtimalini güçlendiriyor.

${ }^{32}$ Miralay Rüştü 22 ve 23 Aralık tarihli iki ayrı şifre tel ile Karabekir'e, Rawlinson'un Mustafa Kemal ile görüşmek istediğini bildirmiş ve kendisinin Milliyetçilere yardımcı olmaya çalıştığını, bunun sonucunda İngiltere'nin Türklerle anlaşmak istediğini, ancak ciddi bir muhatap bulamadığını beyan ederek, Rawlinson'un Mustafa Kemal ile tesadüfi bir görüntü altında bir araya gelmek istediğini, o yüzden Gümüşhane ve Bayburt'ta denetlemeler yapmak bahanesiyle oyalandığını, bu arada Rum piskoposu ile görüşüp, bir maden mühendisi ile madeni ve çevreyi dolaştığını ifade ederek İngiliz subayının mümkün olursa hemen Sivas'a, gerekirse oradan Ankara'ya da gitmek istediğini rapor etmişti. [Bkz. K.Karabekir, İstiklal Harbimiz, s.379 vd.] Konuyla ilgili olarak ayrıca bkz. ATASE Arşivi, Kls. K. 90, Göml. 63, Erzurum'dan Harbiye Nezareti'ne 19.12.1335(19.12.1919) tarihli rapor. 
26 Aralık'ta Erzurum'a gelen Rawlinson, eski İran konsolosluğu binasına yerleşmiş, 28 Aralık'ta Kazım Karabekir ile bir görüşme yapmıştır. Almış olduğu talimatları Karabekir'e bildirmiş, Mustafa Kemal ile görüşmek isteğini yinelemiş̧tir. Karabekir, Mustafa Kemal'in Sivas'a, oradan da Ankara'ya gittiğini söylemiş, Ankara'da Milli Hükümeti kurmakta olduğunu, teklifini kendisine ileteceğini, ancak kış sebebiyle AnkaraErzurum yolculuğunun mümkün olmadığını bildirmiştir. ${ }^{33}$ Aynı görüşmede Rusya hakkında konuştuklarını da belirten Rawlinson, Karabekir'in Avrupa ile bir anlaşmazlık çıktığında Türklerin, ister istemez Bolşeviklerin kollarına atılacağını saklamamakla birlikte, Müttefikler ve özellikle İngiltere ile dostluk kurmayı daha çok istediğini söylemekten çekinmediğini de kaydetmiştir. ${ }^{34}$

20 Kolordu Kumandanlığı aracılığıyla Kazım Karabekir durumu ve görüşmeyi teferruatlı bir şekilde 28 Aralık 1919'da, Mustafa Kemal Paşa'ya şifre telgrafla bildirmiştir. Bu telgrafta özetle; Rawlinson'un görünürde XIII. ve XV. Kolordularda Mütareke şartlarının yerine getirilip getirilmediğini araştırdığı, asıl amacının ise, dikkat çekmeden Karabekir'den sonra Mustafa Kemal ile görüşmek olduğu belirtilmiş, Curzon'un Türkiye'de şimdiye kadar kuvvetli bir hükümet görmediklerinden barışın mümkün olamadı̆̆ını, halen de bir kuvvet göremediklerini, milletin güvenini kazanan Mustafa Kemal Paşa'nın barış konferansında bulunmasını istediklerini söylediğini ve konunun kendisine yazılmasını rica ettikleri yazılmıştı. Ayrıca Rawlinson'un, İngiltere'de pek çok partinin Türkiye'nin varlığ 1 ve bağımsızlı̆̆ına taraf olduğunu, Asya'daki müstemlekelerinin huzurunun buna bağlı olduğunu İngiliz Hükümeti'nin de kabul ettiğini, onun için diğer devletlerin Türkiye'yi taksim planlarına İngiltere'nin izin vermeyeceğini bildirdiği de belirtilmişti. Rawlinson'un ağzından İngiltere, birçok fedakarlıktan sonra Türkiye'nin İngiltere'nin düşmanları tarafına geçmesinden korkulduğunu, yanında getirdiği mühendisle Erzurum ve Gümüşhane bölgesinde maden işletmesi ve demiryolu inşası ile Türkiye'ye külliyetli paralar dökeceklerini ve memleketi mamur hale getireceklerini de söylemiştir. ${ }^{35}$ Ancak Rawlinson hatıratında hatıratında bu konulardan

${ }^{33}$ Rawlinson'un bu görüşmedeki izlenimleri; Karabekir, memleketine teklif edilecek barış şartlarının Türk milletinin görüşlerinden çok uzak, İstanbul ve Müttefikler arasında belirlenen prensipler olarak dikte ettirilmeye çalışılacağından endişeliydi. Kendisine hak verdim ama belli etmedim. Bu sonuçları görebildiğine de hayret ettim. şeklindedir. Bkz. A.Rawlinson, a.g.e., s.282 vd.

${ }^{34}$ Rawlinson Bayburt Rum Piskoposu ile yaptığı görüşmede, "burası Türkiye'dir, defolun Yunanistan'a. Pontus da bașka bir şeyde yoktur deyip terslediğini de Karabekir'e aktarmıştır. [Bkz. A. Rawlinson, a.g.e., s.283] Böylelikle ne kadar Türk sempatizanı olduğunu göstermek istemiş olmalı! Konuyla ilgili olarak ayrıca bkz. ATASE Arşivi, Kls. K. 90, Göml. 63, Erzurum'dan Harbiye Nezareti'ne 19.12.1335 (19.12.1919) tarihli rapor.

${ }^{35}$ Rawlinson, Güney Afrika'daki maden şirketinin kendisiyle Gümüşhane ve Erzurum havalisinde maden arasın diye bir mühendis gönderdiğini, ilk iş olarak şimendifere başlayacaklarını, Türkiye'ye yatırım için külliyetli para dökeceklerini de beyan etmiştir. 
bahsetmediği gibi; Karabekir'in Rawlinson'un sorduğunu iddia ettiği "Cumhuriyet mi padişahlık mı? İstanbul ülkeyi yönetmeye devam edecek mi? Anadolu'nun İstanbul'dan yönetilmesi mümkün mü? Halifelik idareden ayrılacak mı?" gibi sorulara da değinmemiştir. Bu telgrafa Ankara'dan verilen cevapta ise; Rawlinson'un ancak resmi yetkili olması durumunda kendisiyle görüşülebileceği cevabı verilmiştir. ${ }^{36}$

Rawlinson Erzurum'a gelirken Bayburt'ta Rum Piskoposu ile görüşmüştür. Bu görüşmede Rumları payladığını ifade etmektedir. Bu Türk yetkililere şirin gözükmek için bir manevra da olabilir. ${ }^{37}$ Rawlinson'un bu görüşmede ortaya koyduğu yaklaşım, İstanbul'un Türkiye'ye hakim olamadığının İngilizlerce de fark edildiği ve bu devletin çıkarlarını koruyabileceği şartlarda, Türkiye konusunda daha etkin ve dahası, gelecekte Türkiye'yi temsil edeceğini düşündüğü Mustafa Kemal ve ekibi ile anlaşmaya çalıştı̆̆ kanaatini uyandırmaktadır.

Rawlinson'un Karabekir ile yaptı̆̆ı görüşmeden çıkardı̆̆ı sonuç: "Padişah yine hükümete karışacak, mesela Halife olarak siyasete karışmasıın ve nerede oturursa otursun tarzı düşünülmeyecek" şeklindedir. Bu yaklaşım Padişahın Halife sıfatı ile yönetime karıșmamasını istediklerinin ișaretidir. Buradan, Türkler Halifeliği kullanacaklar mı? sorusunun cevabını merak ettikleri sonucu da çıkmaktadır. Bu görüşmede Rawlinson'un dile getirdiği başkaca şeyler de vardır. "Batum'un Denikin'in kontrolüne verilmesine taraftar oldukları, İngiltere Batum'daki birliklerini çektiğinde birçok milletin burası için kavgaya tutuşacağı, İngiltere kamuoyunun Yunanistan aleyhine döndüğğu, İzmir'den mutlaka çıkartılacakları ${ }^{38}$ Ermenilerin esasen bir hükümet teşkil etmelerinin zor olduğu, bütün bunları hükümetine de yazdığı, Aras nehrini Türk-Ermeni sınırı olarak teklif ettiği” gibi açıklamalarda

Görüşme ve yazışmalar için [bkz. K. Karabekir, İstiklal Harbimiz, s.384 vd] Kazım Karabekir ile Heyet-i Temsiliye arasında cereyan eden bu yoldaki yazışmalardan İstanbul da haberdar olmuş ve Harbiye Nezareti Kazım Karabekir'i bu tür ilişkilere tevessül edilmemesi konusunda 2 Şubat 1920'de uyarmıştı. Bkz. K. Karabekir, İstiklal Harbimiz, s.389 vd.

${ }^{36} 8$ ve 9 Ocak 1920 'de Heyet-i Temsiliye adına Mustafa Kemal imzası ve 20. Kolordu vasıtasıyla çekilen şifreli teller için bkz. K. Karabekir, İstiklal Harbimiz, s.387 vd. ve G. Jaeschke, a.g.e., s.148.

${ }^{37}$ Rawlinson Piskopos'a, "Burası Türkiye'dir, defolun Yunanistan'a. Selametiniz için başka çare ve Pontus falan da yoktur dedim.”şeklinde Karabekir'e anlatmıştır. K. Karabekir, İstiklal Harbimiz, s.388, Rawlinson Trabzon'dan Erzurum'a geçerken Bayburt'ta kendisine tahsis edilen evde konakladığı sırada Bayburt Rum Piskoposu gelip, Türklerle ilgili şikayetlerde bulunmuş, buraların Rumlara ait olduğunu ve kendilerine katliam yapıldığını söylemiştir. Rawlinson hatıratında da bu görüşmeden bahsetmiş, Piskopos'a, himayesinde yaşadıkları ve savaş halinde bulundukları Türklerin kendilerine hak ettiklerinden çok daha müşfik davrandıklarını söylemiştir. Bu tavrı sebebiyle kendisinin Rum gazetelerinde tenkit ve İngiltere'ye şikayet edildiğini de yine Rawlinson yazmaktadır. Bkz. A. Rawlinson, a.g.e., s.269.

${ }^{38}$ Michael Llewellyn Smith, Yunan Düșü, Ankara 2002, s. 114 vd. 
bulunmuştur. ${ }^{39}$ Bütün bunlar İngiltere'nin kendi çıkarlarını koruma ve genişletme yolunda kiminle işbirliği kuracağı değil, kendi çıkarlarını nasıl koruyacağını önemsediğinin delilleridir.

Türklerin Rusya ile kurmaya çalıştıkları münasebetlerden çekinen İngiltere, Rawlinson aracılığıyla Türklere hoş görünme yönelik tavırları, adeta rüşvet kabilinden teklifleriyle beraber endişelerini de dile getirmiştir. Esasen bu konularda $\mathrm{O}$, İngiltere'nin bütün fedakarlıklarına rağmen Türkiye'nin, İngiltere'nin düşmanları tarafına geçmesinden korkulduğunu itiraf etmektedir. Bu arada İngiltere, menfaatlerinin sürekliliğini sağlamak ve arttırmak için kendisine yakın kişilerden bir heyetin Türkiye'de ipleri ele almasını da istemektedir. ${ }^{40}$ Ancak Heyet-i Temsiliye ve Mustafa Kemal, Rawlinson'un ciddiye alınması için misyonunun resmi ve açık olarak ortaya konulmasında ısrarcı olmuştur. Bu ilişkinin açığa vurulması ve resmi bir hüviyet kazanması, uluslararası platformlarda Türk Milli Mücadelesi'nin önünü açacak, bazı imkanlar sağlayacaktır.

İngiliz İtilaf Komiseri bir yandan bu görüşmeleri sürdürürken, diğer yandan Sivas Kongresi ve Meclis-i Mebusan'ın toplanması gibi gelişmelerden tedirgindir. Rauf Bey ve arkadaşlarının İstanbul'a gitmesi ve Meclisin toplanması ile durumun nazikleşeceğini tahmin etmektedir. Hayat şartları da zorlaşmıştır. ${ }^{41}$ Gelişmeleri sürekli İstanbul'a bildirmekte, kendisi ve ekibinin hareket tarzı konusunda İstanbul'dan bir görüş beklemektedir. Ama beklediği tavsiye veya emirleri alamayan Rawlinson, kendi inisiyatifiyle Erzurum'daki kafilesini küçültmeye karar vermiş, 2 Mart'ta Türk makamlarının izni ve yardımıyla 2 şoför, iki er ve bir üsteğmeni kızaklarla sahile göndermiştir. ${ }^{42}$ Onlar ayrıldıktan sonra kendisi de bütün hazırlıklarını tamamlayarak hemen harekete geçebilecek bir vaziyette beklemeye başlamıştır.

16 Mart 1920'de İstanbul'un Müttefiklerce resmen işgali ve bazı milletvekillerinin tutuklanması üzerine, İtilaf Komiseri ve İngiliz gizli servis görevlisi Rawlinson, rehin olarak Erzurum'da tutuklanmış, endişelerinde haklı çıkmıştır. Bölgenin en son haritalarından biri üzerinde çalışmalarını tamamlayıp karısına mektup yazmaya başladığı sırada tutuklanmıştır. Silahlarını vermek istememiş ve İngiliz bayrağını indirmeyi reddetmiştir. Valiye kahve ikram etmiş oturup konuşmuşlar. $\mathrm{Bu}$ arada bir fırsatını bulup

${ }^{39}$ Bkz. K. Karabekir, İstiklal Harbimiz, s. 385 vd.

${ }^{40} \mathrm{~K}$. Karabekir, İstiklal Harbimiz, s.385.

${ }^{41}$ Rawlinson Erzurum'da yeteri kadar beslenemediklerinden, sürekli kumlu kara ekmek yemekten hasta olduklarından, kı̧̧ şartlarının zorluğundan bahseder. Bkz. A. Rawlinson, a.g.e.,s. 286 .

${ }^{42}$ A. Rawlinson, a.g.e., s.286 vd. Aslında Rawlinson ve Anadolu'da bulunan İngilizlerin rehin alınması konusunda, askeri ve mülki idareciler Mustafa Kemal tarafından 22 Ocak 1920 'de, her ihtimale karşı tedbir olarak uyarılmıştı. Bkz.K. Atatürk, Nutuk I, İstanbul 1982, s.372. 
evraklarını yok etmiş. ${ }^{43}$ Aynı tarihlerde İstanbul'daki İngiliz yetkililerin Londra ile yazışmalarında ve İstanbul'a gelen raporlarda da; Misak-1 Milli, Rawlinson'un tutuklanması, Mustafa Kemal ve arkadaşları konusunda yönetimin uyarılması konuları işlenmektedir. ${ }^{44}$

Bu gelişmelerden sonra Türk-İngiliz ilişkileri Malta'daki Türklerle Anadolu'daki İngilizlerin mübadelesi konusunda yoğunlaşmıștır. Rawlinson da kendisinin serbest bırakılması konusunda Karabekir'e mektuplar yazmış ve bu gerçekleşirse barış için Türk çıkarlarını koruyacak kişinin de kendisi olacağını beyan etmiştir. Durumu Heyet-i Temsiliye'ye bildiren Karabekir, Erzurum İngiliz temsilcisinin, sürekli kendisine "beni bırakın arabuluculuk edeyim" şeklinde mektuplar yazdığını, 31 Mart tarihli olanın İstanbul İngiliz Karargahına da yazıldığını ve bunun üzerine, Rawlinson'un arabuluculuk yapmasının kabul edildiğini bildirmiştir.

Kazım Karabekir durumu Ankara'ya bildirmiş ve Rawlinson'un isteklerinden Mustafa Kemal'i haberdar etmişti. Karabekir mektup trafiğini

43 Tutuklanma anını Rawlinson şöyle ifade eder: "Dışardan ayak sesleri ve silah şakırtıları duydum. Ansızın kapım arkasına kadar açıldı ve Vali içeri girdi...Türk ordusunun bütün kuvvetiyle burada olduğu şüphesizdi. (Ya kendini çok önemsiyor, ya da Türk ordusunu küçümsüyor) Albay a (Vali) kahve ikram ettim. Oturduk. Albay, Kazım Paşa tarafından gönderildiğini söyledi. İstanbul'daki yeni parlamentoda milliyetçi lider Rauf Bey'in özel temsilcisi olarak seçildiği partinin politikasının (Misak-1 Milli) okunması üzerine, Rauf Bey ve taraftarları tutuklanmış, İstanbul Müttefiklerce resmen işgal edilmiş. Bu sebeple bizi muhafaza altına alma emri verilmiş... Bulunduğumuz yerin güvenli olmadığını, Paşa'nın gösterdiği ilgiyi takdir ettiğimi belirttim. Bayrağımızı indirmeyi ve silahları teslim etmeyi reddettim. Kaleye gidersek güvende olacağımızı söyledim. Albay aldığı emirlerden başka bir şey yapamayacağını söyledi. Teklifimi Paşa'ya götürmesini istedim. Acele ile bunu yazıya döktüm. Karıma yazmağa başladığım mektup kağıdını kullanmışım. Doğrusu Paşa'ya bu kadar sevgi göstermeğe niyetlenmemiştim. Albay mektubu bizzatihi götürdü. Neticeyi biliyordum ama adamı dışarı çıkararak birkaç dakika kazanmayı başardım... Bütün kağıtlarımı, emirlerimi, haberlerimi ve özellikle şifre anahtarlarımı toplayıp sobaya koydum. 10 dakika kadar sonra Albay döndüğünde imha işi tamamlanmıștı. Teklifimiz reddedilmişti. Bayrağı göğsüme yerleştirdim. Silahları teslim edip makbuzunu aldım. Ev bir muhafız birliğince korunuyor, pencereler telle örülüyordu. Ertesi gün uzun süreceğinden emin olduğum tutuklanmamızdan dolayı kırgınlığımı belirten mektuplar yazdım. Bu konuda Karabekir, Rawlinson'un kendisi ile Rauf Bey ve arkadaşlarının mübadele edilmesi teklifini getiren mektuplar yazdığını belirtir. Serbest kalırsa arabuluculuk yapabileceği önerileri de buna dahildir. Rawlinson, Rauf Bey ve arkadaşlarının tutuklanması ve Malta'ya sürgün edilmesine karşılık rehin alınmıştı. Burada bahsedilen Albay, Erzurum Mevki-i Müstahkem Kumandanı Kazım Dirik'tir ve Kolordu'ya verdiği rapora göre, Rawlinson İngiliz bayrağını kendiliğinden indirmiştir. Bkz. Tarih Vesikaları Dergisi, S: 26. Belge: 663, A.Rawlinson, a.g.e., s.287-291, Ayrıca tutuklama için bkz. K. Karabekir, İstiklal Harbimizin Esasları, $\mathrm{s} .62 \mathrm{ve}$ İstiklal Harbimiz, $\mathrm{s} .500 \mathrm{vd}$.

${ }^{44}$ Robeck'ten Lord Curzon'a Osmanlı Meclisi Mebusanı'nın faaliyetleri hakkında 1 Nisan 1920 tarihli rapor ve Curzon'un Rawlinson'un tutuklanması ve Mustafa Kemal ve arkadaşlarının faaliyetleri konusunda yönetimin uyarılması gereğini bildiren yazısı için bkz. Bilal Şimşir, İngiliz Belgelerinde Atatürk II, Ankara 1975, s. 3 vd. 
telgrafta özetlemişti: "Erzurum'da bulunan İngiliz Kaymakamı Rawlinson 19 Mart'ta bana yazdı ğı bir mektupta; Dersaadet'teki İtilaf devletleri temsilcilerinin Milliyetçilerin maksatları ve galeyanın sebeplerinden haberdar olmadan ihdas ettikleri vakalardan teessür ettikleri, son defa Londra'dan Erzurum'a gelişinden başlıca maksadın Milli Hareket'in liderleri ile görüşmek yolunu aramak ve gayri resmi şekilde amirlerine vereceği malumat ile vaziyeti izah ve taraflara hizmet etmekten ibaret olduğunu zikretmiş ve bu münasebetle vaziyeti düzelterek sulh ve sükunun kurulması için çalışmak üzere Ankara'ya hareket ve Heyet-i Temsiliye emrine gitmeye hazır bulunduğunu teklif eylemişti." Bu mektuba hava şartları uygun olmadığından Ankara'ya gitmesinin mümkün olmadığı ve mektubu ifşa etmemesi cevabını verdiğini belirten Karabekir, Rawlinson'un 22 Mart'ta aynı konuda ikinci mektubu yazması üzerine durumu Ankara'ya yazdığını kaydetmişti. Rawlinson ikinci mektupta da; “Ankara'ya gitmesine izin verilmesi durumunda Türklerin menfaatlerinin kendisince en iyi şekilde korunabileceğini, buna izin verilmezse kısa zamanda Tortum'dan Batum'a ve oradan torpido ile Londra'ya gitmeye razı olduğunu yazmıştır..." Kazım Karabekir, Rawlinson'un bir an önce Erzurum'dan kaçmak istediğini, Teklifinden istifade var ise Sivas üzerinden Ankara'ya sevki konusunda emre amade olduğunu yazmıştır. 26 Mart'ta Heyet-i Temsiliye adına Mustafa Kemal'den gelen cevapta ise; Rawlinson'a inanmak istendiği, ancak bunun için Ankara'ya gitmesine gerek olmadı̆̆ı, tutuklanan Türkler serbest kalmadıkça İngilizlerin serbest bırakılmayacağı, kontrol edilmek şartıyla Trabzon üzerinden İstanbul veya Londra'ya bir mektup gönderebileceği, İngilizler niyetlerinde samimiyse Rauf Bey'in bu iş için görevlendirilebileceği belirtilmişti. ${ }^{45}$ İngilizler özellikle Rawlinson'un kurtarılması konusunda hassastılar. Özellikle Lord Curzon, Rawlinson'un serbest bırakılmasını çok istiyordu ve bunun için General Milne'i atlayarak doğrudan De Robeck ile yazışmış ${ }^{46}$ ve anlaşıldığına göre talimat vermişti.

Mübadele için bu tarz girişimleri sürdüren İngiltere, Karabekir'e göre Rawlinson'u kaçırmak için de birçok teşebbüslerde bulunmuştu. ${ }^{47} \mathrm{Bu}$

${ }^{45}$ Yazışmalar için bkz. Atatürk’ün Milli Dış Politikası I, Ankara 1981, s.148-151 ve ayrıca K. Karabekir, İstiklal Harbimiz, s.501.

${ }^{46}$ Rawlinson Curzon'un yeğeninin kocasıydı ve De Robeck'ten Lord Curzon'a 15 Ekim 1920 tarihiyle sunulan raporda esirlerin kurtarılması konusunda bu yolla Türk tarafı ile anlaşmanın mümkün olmadığını belirtmişti. [Bkz. G. Jaeschke, a.g.e., s.187] 18 temmuz 1920 'de de TBMM'de mübadele ile ilgili ilk tartışma yapılmış, Mecliste Rawlinson'un arabuluculuk görevini üstlenmeye hazır olduğunu bildiren mektup okunmuştu. Bkz. TBMM Zabit Cerideleri II, s.335.

${ }^{47}$ Rawlinson Erzurum'da hapishanede bulunduğu sırada, alış veriş için pazara çıkmasına izin verilen adamı aracılığıyla irtibat kurdukları bir Ermeni'nin kendilerini kaçırmak için teşebbüste bulunduğunu kaydeden Rawlinson, [Bkz. A. Rawlinson, a.g.e., s.308-312] 1921 Mart ayı sonunda mübadele için götürülmüş, tarafların anlaşamaması üzerine Erzurum'a geri döndürülmüştü. Bu dönüş yolculuğuna çıkarken Trabzon'dan İstanbul'a yazdığı bir mektupla kendilerinin kaçırılabileceği uygun yerleri (Rize-Trabzon arasındaki Of) 
girişimlerden sonuç alınamamış, ancak 1921 başında Londra Konferansı'nda Bekir Sami Bey'in şahsi tasarrufu olarak imzaladığı Türk-İngiliz ikili anlaşmasında bu konu da yer almıştı. Ankara'da Meclis bu anlaşmayı tanımamakla birlikte, mübadele konusundaki girișimler devam etti. Hatta 24 Mart 1921'de Rawlinson ve adamları mübadele için Trabzon'a götürülmüş ve olumsuz bazı gelişmelerden dolayı Erzurum'a geri getirilmişti. ${ }^{48}$

1921 Haziran ayı başlarında bu defa İstanbul'daki Müttefik Kuvvetleri Başkumandanı General Harington adına bazı İngiliz subayları Ankara ile irtibata geçip Harington'un Mustafa Kemal Paşa ile görüşmek istediğini bildirmişlerdi. ${ }^{49} \mathrm{Bu}$ da gizli ve resmi olmayan bir yaklaşım olarak gündeme gelmiş, tarafların görüşmesi mümkün olmamıştı. Rawlinson ve Anadolu'da tutulan İngilizlerin kurtarılması konusunda yeni ve başarısız bir teşebbüs olarak kalmıştı. ${ }^{50}$

$\mathrm{Bu}$ arada Rawlinson kaldığı evden genel hapishaneye nakledilmiştir. Rawlinson hapishanedeki hayatını uzun uzadıya anlatır. Hapishanenin bazı odalarının Erzurum'dan geçen Türk subayları için boş tutulduğunu söyleyen Rawlinson; bir gün Doğu'dan gelen üç subayın kendisini ziyaret ettiğini, maksatlarının kendi görüşlerini Müttefiklere iletmek için kendisini bir kanal olarak kullanmak ve Rauf Bey'le mübadele etmek olduğunu ifade $e^{5}{ }^{51}$ Rawlinson'un da gizli ve resmi olmayan misyonu buydu. Demek ki taraflar birbirlerini anlıyorlardı. Aynı maksatla Nuri Paşa'nın da hapishanede kendisini ziyaret ettiğini belirten Rawlinson, kendi kurtuluşunun Rauf

amirine bildirmiștir. [Bkz. A. Rawlinson, a.g.e., s.327-332]. Yine bir defasında Rawlinson’a İstanbul'dan gönderilen gizli bir mektubu ökçesi içinde getiren kurye, mektubu Karabekir'e teslim etmiștir. K. Karabekir, İstiklal Harbimiz, s.387.

${ }^{48}$ Bu yolculuk için bkz. A.Rawlinson, a.g.e., s.318 vd. Londra Konferansı'nda Bekir Sami Bey'in İngiltere ile imzaladığı ikili anlaşmanın TBMM'ce geçersiz sayılmasına rağmen, İngilizlerin Malta'daki Türklerden bazılarını serbest bırakması üzerine iyi niyet göstergesi olarak, Anadolu'da tutuklu bulunan bazı İngilizler de serbest bırakılmıştır. Bkz. K. Atatürk, Nutuk II, s.587.

${ }^{49}$ ATASE Arşivi, Kls. 615, D. 206, F. 62,66 ve Cumhurbaşkanlığı Arşivi, A-III-7, D.18, F.84/13. Bu konuda geniş bilgi için bkz. Rahmi Doğanay, "Kurtuluş Savaşı'nın Diplomatik Bir Cephesi İnebolu”, Atatürk Yolu, Mayıs 1998, Sayı: 21, s.49-65.

${ }^{50}$ Tutsakların kurtarılması veya İngilizlerin elindeki Türk esirlerle mübadelesi konusu, aslında hep canlı kalmıştı.11 Şubat 1921'de Rawlinson Karabekir'e, Sovyetlere karşı bir Türk-İngiliz ittifakı önerir.[B.A. BEO, Cevdet tasnifi, Siyasi, D.54, Belge:345394] Londra Konferansı'ndan sonra da Mustafa Kemal'in bir iyi niyet gösterisi olarak, İngiliz tutsakların Karadeniz limanlarından birinde serbest bırakılması önerilir. [Bkz. Bilal Şimşir, İngiliz Belgelerinde Atatürk III, Ankara 1979, s. 270] Esir değişimiyle ilgili olarak 1921 temmuz ayı sonunda Samsun'a iki İngiliz torpidosu gelmiş ve bir mektup vermişlerdi. Ankara'nın talimatıyla, bu konuda görüşmek Türk yetkililer tarafından reddedildi. Bkz. ATASE Arşivi, Kls.1225, D.14, F.41/1

${ }^{51}$ A.Rawlinson, a.g.e., s. 345 . 
Bey'in İngilizlerin elinde olmasına ve Türklerin de Rauf Bey'i çok önemsemelerine bağlamaktadır. ${ }^{52}$

Londra Konferansı'nda başlayan resmi sürecin bazı aksaklıklara rağmen yürümesi ve İngiltere'nin Malta'daki Türkleri bırakmayı kabul etmesi sonucu mübadele anlaşması yapılmış ve 2 Ekim'de, üç gün sonra mübadele edilmek üzere Trabzon'a hareket edileceği bildirilmiş, 14 Ekim'de Trabzon'a gelen kafile dul bir Rum olan Madam Kosvekis'in evine yerleştirilmiş, 31 Ekim öğleden sonra limana gelen bir İngiliz zırhlısı ile İnebolu'ya götürülmüş ve 1 Kasım 1921 tarihinde İnebolu'da mübadele gerçekleştirilmiştir. $^{53}$

Türk-İngiliz ilişkileri açısından bir barışın müjdecisi olamayan bu süreç, hiç olmazsa tarafların birbirlerini ve amaçlarını daha yakından tanımak konusunda önemli katkılar sağlamıştır. Rawlinson ve Harington gibilerin Anadolu'da görüp tespit ettikleri gerçekler, geç de olsa İngiliz bürokratları tarafından kabul edilmiş, dahası Türk ve Türkiye gerçeğini anlamak zorunda kalmışlardır.

Rawlinson serbest kaldıktan sonraki mütalaalarında, "Türkiye ile dostane münasebetler kurmak, eğer mümkünse memleketimizin esaslı politikası olmalıdır. Bizim çektiklerimizin Türk aleyhtarı bir partinin elinde bir silah olarak kullanılmasına müsaade etmemek niyetindeydim. Kaldı ki; bize yapılan muamelenin küçük subayların cahilliğinin ve görevlerini ihmal etmemelerinin sonucu olduğuna inanıyordum. Münferit ihmalleri ele alarak umumi efkarı bütün bir millete karşı ayaklandıracak yerde, bütün mesele daha geniş bir görüşle incelenmelidir." ${ }^{54}$ şeklinde yaptığ değerlendirmelerle de, biraz geç de olsa gerçekleri teslim etme basiretini gösterebilmiştir.

\section{KAYNAKLAR}

Akgün, Seçil, General Harbord'un Anadolu Gezisi ve Ermeni Meselesine Dair

Raporu, İstanbul 1981.

ATASE Arşivi, Kls. 76, 88, 90, 615, 1225.

Atatürk, K., Nutuk I, İstanbul 1982.

, Nutuk II, İstanbul 1982.

Başbakanlık Osmanlı Arşivi

Birinci Dünya Harbinde Türk Harbi, Kafkas Cephesi, Ankara 1993.

${ }_{52}^{52}$ Bu konularda geniş bilgi için bkz. A. Rawlinson, a.g.e.,s.344 vd.

${ }^{53}$ Mübadele konusunda geniş bilgi için bkz. Rahmi Doğanay, "Milli Mücadele'de Türkİngiliz Esir Değişimi”, F.Ü. Sosyal Bilimler Dergisi, X/ 1, Ocak-Haziran 2000, s.69-78, B. Şimşir, Malta Sürgünleri, Ankara 1985, s.389-405.

${ }^{54}$ A.Rawlinson, a.g.e., s.363, 
Cumhurbaşkanlığı Arşivi, A-III-7, D.18.

Doğanay, Rahmi, “ Kurtuluş Savaşı'nın Diplomatik Bir Cephesi İnebolu”, Atatürk Yolu, Mayıs 1998, Sayı: 21, s.49-65.

Doğanay, Rahmi, "Milli Mücadele’de Türk-İngiliz Esir Değişimi”, F.Ü. Sosyal Bilimler Dergisi, X/ 1, Ocak-Haziran 2000.

Dursunoğlu, Cevat, Milli Mücadele'de Erzurum, Ankara 1946.

Harp Tarihi Vesikalar Dergisi, Sayı: 3, Belge, 49

Hopkirk, Peter, İstanbul'un Doğusunda Bitmeyen Oyun, İstanbul 1995.

Jaeschke, Gotthard, Kurtuluş Savaşı ile İlgili İngiliz Belgeleri, Ankara 1986.

Kansu, M. Müfit, Erzurum'dan Ölümüne Kadar Atatürk’le Beraber I, Ankara 1966.

Karabekir, Kazım, İstiklal Harbimiz, İstanbul 1988.

, İstiklal Harbimizin Esasları, İstanbul 1995.

-, Enver Paşa ve İttihat ve Terakki Erkanı, İstanbul 1990.

Kırzıoğlu, Fahrettin, Türk İnkılap Tarihi Dersleri, Erzurum 1977.

Rawlinson, Alfred, Adventures in The Near East, London 1923.

Smith, Michael Llewellyn, Yunan Düşü, Ankara 2002.

Sonyel, Salahi R., Kurtuluş Savaşı Günlerinde İngiliz İstihbarat Servisi’nin Türkiye'deki Eylemleri, Ankara 1995.

Türk Kurtuluş Savaşı ve Dış Politika I, Ankara 1987.

, “1919 Yılı İngiliz Belgelerinin Işı̆̆ında Mustafa Kemal ve Milli Mukavemet”, Türk Külttürü, Yı1:1969, Sayı: 85.

Sorgun, Taylan, Halil Paşa İttihat ve Terakki'den Cumhuriyet'e Bitmeyen Savaş, İstanbul 1997.

Şimşir, Bilal, İngiliz Belgelerinde Atatürk I, Ankara 1973.

, İngiliz Belgelerinde Atatürk II, Ankara 1975.

, İngiliz Belgelerinde Atatürk III, Ankara 1979.

, Malta Sürgünleri, Ankara 1985.

Tansel, Selahattin, Mondros'tan Mudanya'ya II, İstanbul 1991.

Tarih Vesikaları Dergisi, S: 26. Belge: 663.

TBMM Zabit Cerideleri II. 